\title{
Effects of atrazine and nicosulfuron on periphytic diatom communities in freshwater outdoor lentic mesocosms
}

\author{
F. Seguin 1,4 \\ J.-C. Druart ${ }^{2}$ \\ R. Le Cohu ${ }^{3}$
}

Keywords : Ecotoxicology, herbicides, aquatic mesocosms, periphyton.

One of the agro-environmental characteristics of Brittany is the extensive use of pesticides, which leads to high concentrations of atrazine in continental water systems. Periphytic algae play a basic part in aquatic ecosystems and some of them, diatoms, are highly sensitive to environmental changes. Analyses of diatoms can thus indicate the impact of a herbicide on aquatic systems. We compared the effects of two herbicides (atrazine and nicosulfuron) on an aquatic ecosystem in 1998. This study was conducted in 15 identical ponds, each containing a holder for installing artificial substrates. The periphytic diatoms were analysed for cell density, biomass, species diversity and morphology. The general specific diversity was poor, and the diatom community was essentially dominated by Achnanthidium minutissimum. The first results showed a strong similarity between the different categories of mesocosms. Chlorophyll $a$ concentration only seems to be affected by high herbicide concentrations.

Effets de deux herbicides (atrazine et nicosulfuron) sur les diatomées du périphyton : approche expérimentale en mésocosmes aquatiques lentiques

Mots-clés : Ecotoxicologie, herbicides, mésocosmes aquatiques, périphyton.

Le contexte agro-environnemental de Bretagne est caractérisé par l'utilisation importante de pesticides et par des concentrations parfois élevées en atrazine dans les écosystèmes aquatiques. Les algues du périphyton jouent un rôle fondamental sur le plan fonctionnel de ces écosystèmes et certaines, les diatomées, ont la particularité de présenter une forte sensibilité aux changements environnementaux. L'analyse de ce compartiment diatomique est justifiée dans le cadre d'une étude d'impacts d'herbicides en milieu aquatique. Une expérimentation visant à comparer les effets de deux herbicides (atrazine et nicosulfuron), sur un écosystème aquatique a été effectuée en 1998. Cette étude a été réalisée dans 15 mésocosmes-réplicats. Chaque mésocosme comporte un dispositif permettant la mise en place de substrats artificiels destinés à l'échantillonnage périodique du périphyton. Les diatomées du périphyton ont été analysées selon quatre critères : densité cellulaire, diversité, biomasse et morphologie. D'une manière générale on a observé une faible diversité spécifique et un peuplement largement dominé par Achnanthidium minutissimum. Les premiers résultats ont montré une forte similitude entre les différentes catégories de mésocosmes. Seule la teneur en chlorophylle $a$ semble être affectée par les fortẹs teneurs en herbicides.

1. INRA, Laboratoire d'Ecologie Aquatique, 65 rue de Saint Brieuc, 35042 Rennes Cedex, France.

2. INRA, Station d'Hydrobiologie Lacustre, 75 av. de Corzent, B.P. 511,74203 Thonon-Les-Bains, France.

3. Centre d'Ecologie des Systèmes Aquatiques Continentaux, UMR 5576 CNRS, Université Paul Sabatier, 118 route de Narbonne, 31062 Toulouse Cedex 04, France.

4. Corresponding author : seguin@roazhon.inra.fr 


\section{Introduction}

Intensive agriculture has been using more and more herbicides for some years. Increased plant production (cereals) leads to massive herbicides consumption, and consequently to abnormally high concentrations in surface waters (runoff from agricultural field treated with atrazine during the post-application period) (Bérard \& Pelte 1996). Atrazine levels can be up to $30 \mu \mathrm{g} . \mathrm{l}^{-1}$ in Brittany (Giovanni \& Haury 1995). Atrazine inhibits the photosysthem II, and may thus damage the microflora of rivers and lakes (phytoplankton; periphyton and macrophytes) (Bérard \& Pelte 1999).

It is thus necessary to develop ways of detecting the effects of herbicides on the environment, in order to assess contamination hazard caused by agricultural practices. Many laboratory tests are used to assess the xenobiotic effects on a single species (monospecific tests). However, they are clearly not very relevant to the whole environment. Aquatic mesocosms, which are small-scale artificial ecosystems placed under natural environment conditions (Odum 1984), possess most of the structural and functional characteristics of the field they intended to model. The bioavailability and toxicity of pesticides can be assessed using a representative set of natural aquatic ecosystems (Crossland 1994, Touart 1994). Environmental realism is the main reason for using mesocosm instead of less complex experiments (Kraufvelin 1998). Studies on mesocosms are, in this respect; an interesting alternative, since they estimate the effects of a toxic compound on a reconstituted ecosystem (Crossland 1994).

Periphyton algae, which are major components of aquatic trophic chains, are one of the plant communities that are targets of herbicides. The periphyton is a complex community made up of algae, bacteria, fungi, protozoa and invertebrates developing on an underwater substratum. The community functions as an autonomous ecosystem, with both autotrophic and heterotrophic phenomena (Eulin 1997). Periphyton, and particularly attached diatoms, are the dominant primary producers in small rivers (Schagerl et al. 1998). Any qualitative or quantitative change in periphytic diatomic populations has consequences for the whole trophic web (DeNoyelles 1982). Periphytic diatoms have been extensively studied during the last 10 years, and they have been used as indicators of water system quality (Lecointe et al. 1993, Prygiel et al. 1996, Whitton \& Rott 1996, Vinebrooke \& Graham 1997). Some of their most interesting properties are very fast growth, high taxonomic and physiological diversity, and their presence in all aquatic ecosystems (Lowe et al. 1996).
Many species are also used for monospecific tests and their sensitivity to many toxicants is well documented (e. g. Seguin et al. 2001). Periphitic diatoms can reveal both physical and chemical perturbations, and are thus sound indicators of water quality.

This study was done to compare the effect of 2 herbicides on periphytic diatoms. One was atrazine, usually used on corn crops, and nicosulfuron, a more recent sulfonylurea that prevents the synthesis of isoleucine, leucine and valine by inhibiting acetolactate synthase (Simpson et al. 1995). It may thought of as a substitute, at least partial, for atrazine. The study was conducted in aquatic mesocosms using toxicant concentrations generally found in western France, in particular in Brittany, to improve environmental realism.

\section{Materials and methods}

\subsection{Mesocosms}

The experiment lasted two months and was done in experimental ponds (15 large circular tanks) at the $\mathrm{IN}$ RA (Institut National de la Recherche Agronomique, Rennes, France) experimental platform. Each mesocosm (Fig. 1) was $3.2 \mathrm{~m}$ in diameter, $1.2 \mathrm{~m}$ high, and held approximately 5000 liters. A crane and the funnelshaped base of the tank were used to drain the system.

A 7-cm layer of natural sediment taken from a local uncontaminated pond was first placed in each mesocosm. They were then filled with a mixture of tap water and pond water from a nearby site to stock them with phytoplankton and zooplankton. Pond water was pumped into the pelagic zone. The depth of the water mesocosm was $0.7 \mathrm{~m}$. The physico-chemical parameters of the mesocosm are shown in Table 1.

Aquatic macrophytes (Glyceria maxima) were also introduced in each mesocom in two concentric circles to obtain a structure similar to stillwater fish spawning areas (Bry 1996). Glyceria tolerate deep water and are shelters for young fishes.

Artificial substrata (glass slides) were placed in a holder and installed at a constant depth. They were used for periodic sampling of the periphyton and we-

Table 1. Main water nutrient concentrations and temperature in the mesocosms.

Tableau 1. Principales caractéristiques de l'eau des mésocosmes. orthophosphate (mg P/L)

inorganic nitrogen ( $\mathrm{mg} \mathrm{N} / \mathrm{L}$ )

mean temperature

minimum

maximum
0,0065

0,51

$18^{\circ} \mathrm{C}$

$14,4^{\circ} \mathrm{C}$

$24,8^{\circ} \mathrm{C}$ 


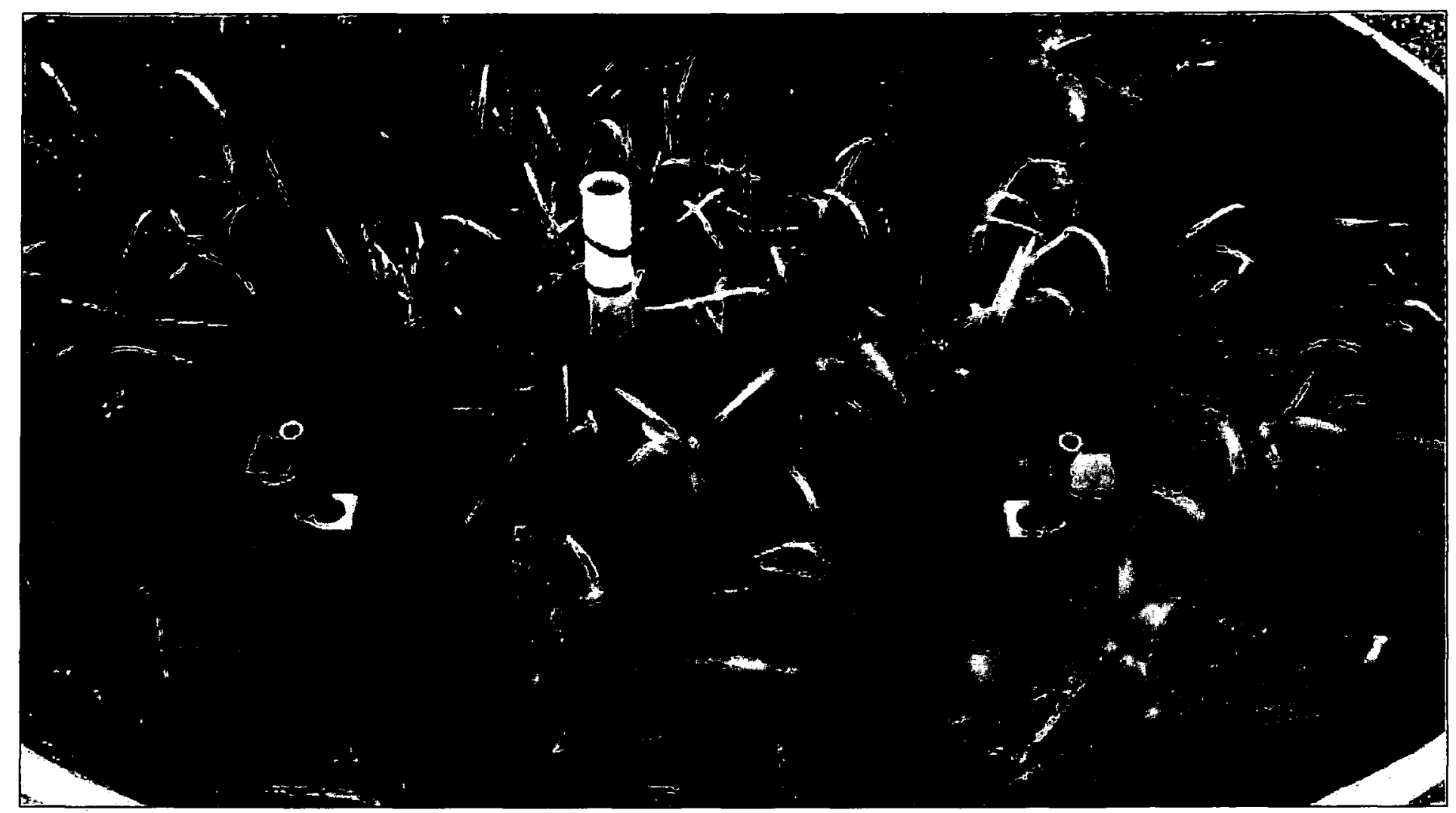

Fig. 1 Overall view of a mesocosm.

Fig. 1. Vue d'ensemble d'un mésocosme aquatique.

re placed in each mesocosm one month before the contamination. Artificial substrata are often employed for taking quantitative samples of periphyton within enclosures like mesocosms. Müller (1995) found that the maximum chlorophyll in epiphyton on Phragmites australis was located in the middle sections of the submerged parts. The slides were therefore placed vertically in the water column about $30 \mathrm{~cm}$ from the water surface (i. e. in the middle of the water column).

\subsection{Contamination procedure}

The biological communities were allowed to come to physical, chemical and biological equilibrium for one month during which time there was colonization of the artificial substrates by periphyton. The mesocosms were then contamined using 2 nominal concentrations of atrazine and nicosulfuron ( 2 and $\left.30 \mu \mathrm{g} \cdot \mathrm{l}^{-1}\right)$. Three microcosms were used for each concentration of each herbicide and three served as untreated controls. The concentrations used ( 2 and $30 \mu \mathrm{g} . \mathrm{l}^{-1}$ ) are those found chronically or after application in surface water in Brittany (Giovanni \& Haury 1995). The contamination of the microcosms was designed to simulate the runoff from agricultural field treated with herbicide.

\subsection{Periphyton sampling}

The periphyton on four glass slides randomly selected were collected from each mesocosm on the day prior to starting treatment and on days 1, 7, 17 and 37 after contamination. The algae were scraped off with a razor blade from the surface of the four slides (Pérès et al. 1997).

Half of each sample was filtered through a Whatman GF/C glass fiber filter for chlorophyll determination. Chlorophyll $a$ was extracted in $90 \%$ acetone for $24 \mathrm{~h}$ at $4^{\circ} \mathrm{C}$ according to Millerioux (1975) and was measured spectrophotometrically according to Jeffrey \& Humphrey (1975).

The remaining volume was preserved in $5 \%$ formalin. A subsample of preserved solution was counted, without identification of species, using the Utermöhl method (1958) with an inverted microscope. An aliquot was mounted in high refractive index medium (Naphrax, Northern Biological Supplies Ltd, UK ; RI $=1.74$ ) for microscopy. About 400 frustules per samples were identified. We measured the frustule size of the most commonly encountered diatoms to detect any possible effect of pesticides on algae morphology. 


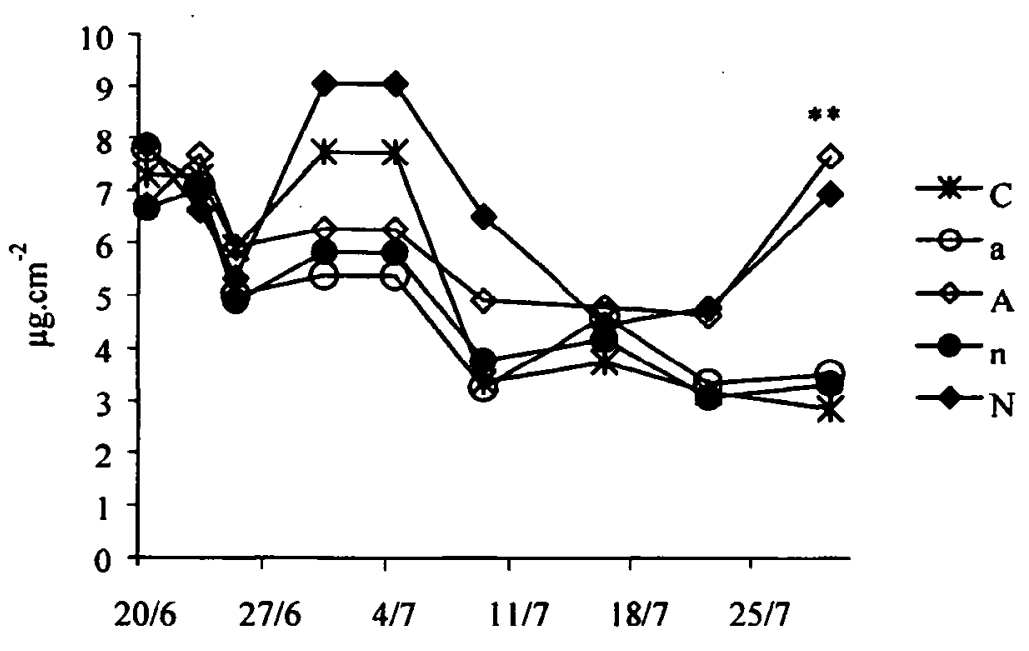

Fig. 2. Growth of periphyton in mesocosms, measured by concentration of chlorophyll $a .\left(\mathrm{C}=\right.$ control ; a $=$ atrâzine $2 \mu \mathrm{g} .1^{-1} ; \mathrm{A}=$ atrazine $30 \mu \mathrm{g} . \mathrm{l}^{-1} ; \mathrm{n}=$ nicosulfuron $2 \mu \mathrm{g} . \mathrm{l}^{-1} ; \mathrm{N}=$ nicosulfuron 30 $\left.\mu \mathrm{g} . \mathrm{l}^{-1}\right)$. Symbols are average values for three replicates. Asterisks $(*)$ indicate significant differences between treatment and control.

Fig. 2. Evolution de la croissance des algues périphytiques, évaluée par des mesures de chlorophylle $a$. $(\mathrm{C}=$ control ; $\mathrm{a}=$ atrazine 2 $\mu \mathrm{g} . \mathrm{l}^{-1} ; \mathrm{A}=$ atrazine $30 \mu \mathrm{g} . \mathrm{l}^{-1} ; \mathrm{n}=$ nicosulfuron $2 \mu \mathrm{g} . \mathrm{l}^{-1} ; \mathrm{N}=\mathrm{ni}-$ cosulfuron $\left.30 \mu \mathrm{g} \cdot \mathrm{l}^{-1}\right)$. Chaque symbole correspond a la moyenne de trois réplicats. Les astérisques $\left(^{*}\right)$ indiquent les différences significatives entre les mésocosmes contaminés et les mésocosmes témoins.

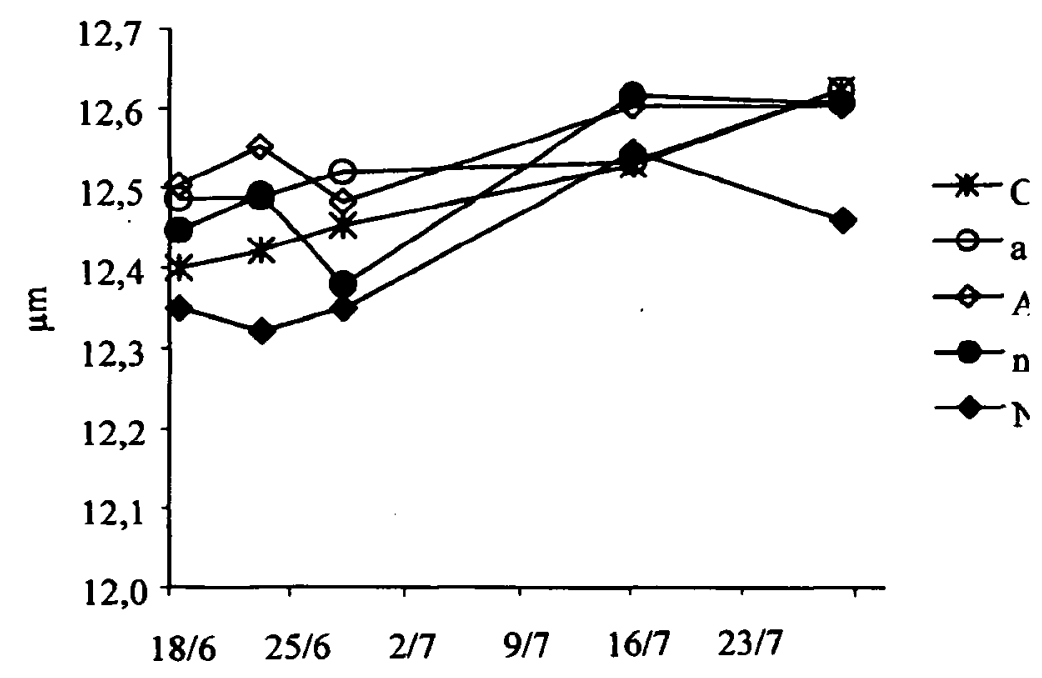

Fig. 4. Length of Achnanthidium minutissimum $(\mathrm{C}=$ control ; $\mathrm{a}=$ atrazine $2 \mu \mathrm{g} . \mathrm{l}^{-1} ; \mathrm{A}=$ atrazine $30 \mu \mathrm{g} . \mathrm{l}^{-1} ; \mathrm{n}=$ nicosulfuron $2 \mu \mathrm{g} . \mathrm{l}^{-}$ ${ }^{1}$; $\mathrm{N}=$ nicosulfuron $30 \mu \mathrm{g} . \mathrm{l}^{-1}$ ). Symbols are average values for three replicates.

Fig. 4. Evolution de la taille des Achnanthidium minutissimum. $(\mathrm{C}=$ control ; $\mathrm{a}=$ atrazine $2 \mu \mathrm{g} . \mathrm{l}^{-1} ; \mathrm{A}=$ atrazine $30 \mu \mathrm{g} . \mathrm{l}^{-1} ; \mathrm{n}=$ nicosulfuron $2 \mu \mathrm{g} . \mathrm{l}^{-1} ; \mathrm{N}=$ nicosulfuron $\left.30 \mu \mathrm{g} . \mathrm{l}^{-1}\right)$. Chaque symbole correspond à la moyenne de trois réplicats.

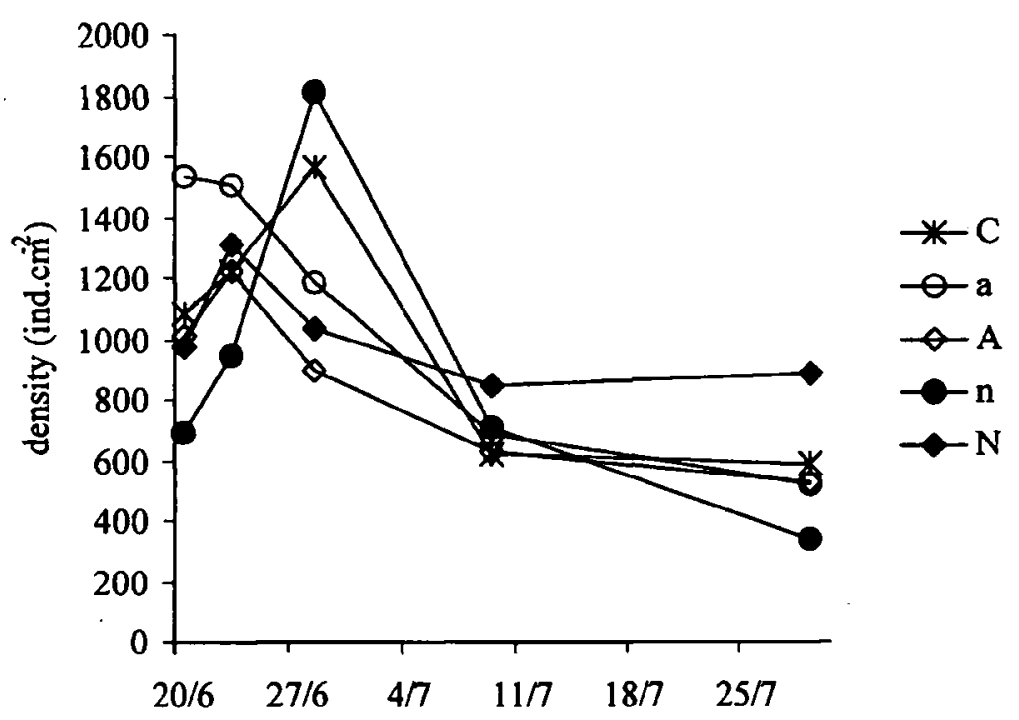

Fig. 3. Changes in density of diatoms. $(\mathrm{C}=$ control ; a $=$ atrazine $2 \mu \mathrm{g} \cdot \mathrm{l}^{-1} ; \mathrm{A}=$ atrazine $30 \mu \mathrm{g} \cdot \mathrm{l}^{-1} ; \mathrm{n}=$ nicosulfuron $2 \mu \mathrm{g} . \mathrm{l}^{-1} ; \mathrm{N}=$ nicosulfuron $30 \mu \mathrm{g} . \mathrm{l}$ 1). Symbols correspond to average values for three replicates.

Fig. 3. Evolution de la densité des diatomées périphytiques. $(\mathrm{C}=$ control ; $\mathrm{a}=$ atrazine $2 \mu \mathrm{g} . \mathrm{l}^{-1} ; \mathrm{A}=$ atrazine $30 \mu \mathrm{g} . \mathrm{l}^{-1} ; \mathrm{n}=$ nico-

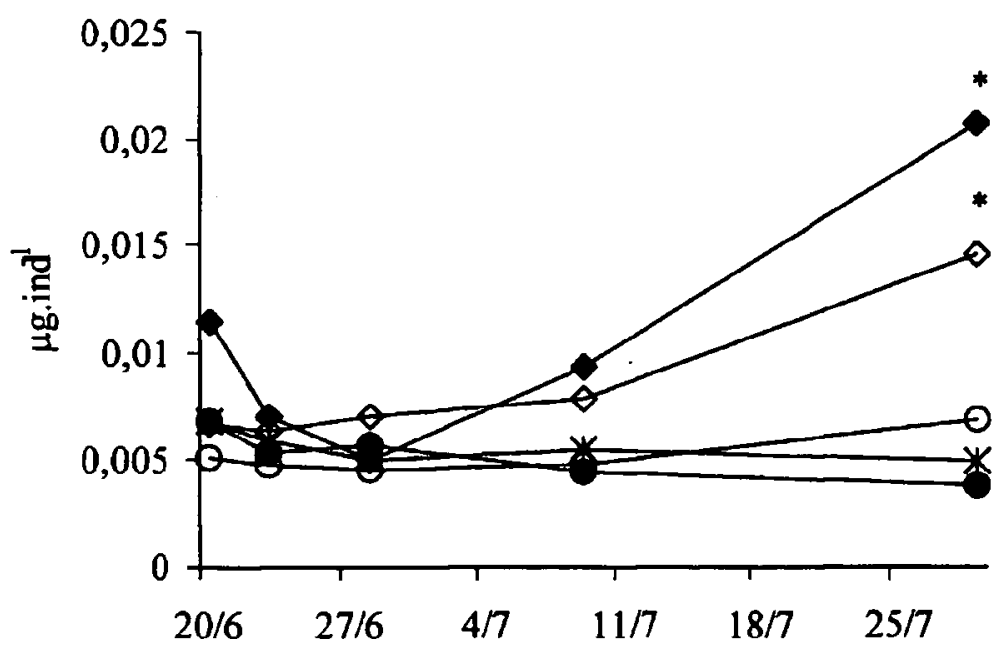

Fig. 5. Change in chlorophyll $a$ in cells $(C=$ control $; a=$ atrazine 2 $\mu \mathrm{g} . \mathrm{l}^{-1} ; \mathrm{A}=$ atrazine $30 \mu \mathrm{g} . \mathrm{l}^{-1} ; \mathrm{n}=$ nicosulfuron $2 \mu \mathrm{g} . \mathrm{l}^{-1} ; \mathrm{N}=\mathrm{ni}-$ cosulfuron $30 \mu \mathrm{g} . \mathrm{l}^{-1}$ ). Symbols are average values of three replicates. Asterisks $\left({ }^{*}\right)$ indicate significant differences between treatment and control.

Fig. 5. Evolution du contenu cellulaire en chlorophylle $a$. $(\mathrm{C}=$ control ; a = atrazine $2 \mu \mathrm{g} . \mathrm{l}^{-1} ; \mathrm{A}=$ atrazine $30 \mu \mathrm{g} . \mathrm{l}^{-1} ; \mathrm{n}=$ nicosulfuron $2 \mu \mathrm{g} .1^{-1} ; \mathrm{N}=$ nicosulfuron $\left.30 \mu \mathrm{g} .1^{-1}\right)$. Chaque symbole correspond à la moyenne de trois réplicats. Les astérisques $\left(^{*}\right)$ in diquent les différences significatives entre les mésocosmes contaminés et les mésocosmes témoins. 


\section{Results}

The periphyton biomass was low, $2.8-9 \mu \mathrm{g} . \mathrm{cm}^{-2}$ (measured by the concentration of chlorophyll $a$ ) (Fig. 2). A Mann-Whitney test was used to compare the control and contaminated mesocosms at each sampling. There was a significant increase in chlorophyll $a$ concentration in mesocosms contaminated with $30 \mu \mathrm{g} \cdot \mathrm{l}^{-1}$ of the 2 toxicants 40 days after contamination.

The algal density showed that the community was $99 \%$ pennate diatoms. We therefore studied only this taxonomic group. The diatom density was very low. There were no significant differences in the densities of the test and control mesocosms (Fig. 3).

Taxonomic analysis showed that the community contained mainly one species, Achnanthidium minutissimum (Kütz) Czarnecki. Other species, such as Cymbella minuta (Hilse), Gomphomema angustatum (Kütz) and Gomphonema parvulum (Kütz), were also found, but at very low percentages.

Morphological analysis of Achnanthidium minutissimum revealed no noticeable size effect or valve distortion due to the herbicides (Fig. 4).

\section{Discussion}

We find no striking effect of the herbicides studied on periphyton. Our inoculum came from the pelagic zone of a pond, as a result there were very few periphytic algae. This may explain the single species in our periphytic community after one month.

The chlorophyll $a$ concentrations of communities exposed to $30 \mu \mathrm{g} . \mathrm{l}^{-1}$ of atrazine and $30 \mu \mathrm{g} . \mathrm{l}^{-1}$ of nicosulfuron for 40 days increased significantly (Fig. 2). The cell density was not affected by any of the treatments (Fig. 3). The significant increase in chlorophyll $a$ at high herbicide concentrations reflects a "greening", with an increase in chlorophyll $a$ concentration inside the cells (Fig. 5). Pratt et al. (1988) noticed the same phenomenon for algae exposed to 3.2 and $32 \mu \mathrm{g} .1^{-1}$ atrazine. Algae exposed to atrazine show an increase in pigment in their antennae in order to maintain an efficient conversion of light energy into chemical energy (Dahl 1996, Dahl \& Blanck 1996). Guash \& Sabater (1998) suggested that the reduced sensitivity of periphyton algal communities adapted to low-light (diatoms) reflect more chlorophyll content per photosynthetic unit.

But other similar studies did not lead to similar conclusions, and showed no increase in chlorophyll $a$ (Jurgensen et al. 1990, Kosinski et al. 1984, Krieger et al. 1988).
We found no difference in the species diversity in controls and treated tanks. Two types of response have been found in other studies. Some report an increase in specific diversity (Pratt et al. 1988, Kosinsky et al. 1984). Hamala \& Kollig (1985) used $100 \mu \mathrm{g} .1^{-1}$ atrazine and found a decrease in specific diversity.

We noticed no shift in the structure of the algal population during the experiments. The community was almost exclusively the small diatom Achnanthidium minutissimum. Some studies on triazines have shown that large filamentous chlorophytes were replaced by smaller diatoms in treated communities (Gurney \& Robinson 1989, Herman et al. 1986, Kasai 1999). The selection pressure exerted by triazine herbicides seemed to be more intense for green algae than for diatoms (Kasai 1999). Guash \& Sabater (1998) found that periphyton algal communities adapted to high-light conditions, i. e. green algae or cyanobacteria, were more sensitive to atrazine than those communities adapted to low-light conditions, diatoms.

Atrazine and nicosulfuron seemed to have no significant effect on algal cell morphology. Van Den Brink et al. (1997) conducted an experiment in microcosms and found that linuron decreased the size of the diatom Cocconeis sp.

Nicosulfuron had the same effect as atrazine on communities, causing a significant rise in the cell content of chlorophyll $a$. Very few studies have been done on the effect of nicosulfuron on periphyton. Experiments with another sulfonylurea, chlorsulfuron, on phytoplanctonic communities showed a decrease in specific diversity (Abel-Hamid et al. 1996). However, chlorsulfuron affects the phytoplankton species composition at $1 \mu \mathrm{g} .1^{-1}$ Källqvist \& Romstad (1994). Nyström et al. (1997) demonstrated that the metabolic activity of periphyton communities can be affected by very low concentrations of sulfonylurea herbicides under certain conditions.

\section{Conclusion}

Atrazine and nicosulfuron, at concentrations typical of those found in Brittany surface water after agricultural runoff, had significant effects on chlorophyll $a$ content of periphyton, but there was no change in species composition. The response of periphyton to herbicides depends on the herbicide concentration, the duration of exposure and on the species composition of the periphyton (Gurney \& Robinson 1989). We believe that the present study is one of the first attempts to quantify and compare the effects of atrazine and nicosulfuron on periphyton. Aquatic mesocosms provide a simple way of simulating the effects of herbicides on a reconstituted ecosystem. 


\section{Acknowledgments}

E. Menthon, P.-M. Lucas and the U3E staff are acknowledged for technical help. The authors are greatly indebted to $\mathrm{C}$. Bry for his assistance during this study. This research was supported by the PNETOX (Programme National d'EcoTOXicologie) financed by the MATE (Ministry of Environment) and INRA (Institut National de la Recherche Agronomique). The English text was edited by Dr. Owen Parkes.

\section{References}

Abdel-Hamid M.I., Källqvist T., Hessen D.O. \& Berge D. 1996. The use of enclosure experiments to study the effect of pesticides on lake plankton. Lakes \& Reservoirs : Reasearch and Management, 2 : 199-209.

Bérard A. \& Pelte T. 1996. — Effets de l'atrazine sur l'évolution des peuplements phytoplanctoniques lacustres. Etude en enceintes expérimentales in situ. Ecologie, 27 (4) : 195-201.

Bérard A. \& Pelte T. 1999. - Les herbicides inhibiteurs du photosystème II, effets sur les communautés algales et leur dynamique. Rev. Sci. Eau, 12 (2) : 333-361.

Bry C. 1996. - Role of vegetation in the life cycle of pike, In Pike : biology and exploitation. Craig, J.F., Chapman \& Hall (eds.), London, $\mathrm{p}$ : 45-57.

Crossland N.O. 1994. - Extrapoling from mesocosm studies to the real world. Toxicol. Ecotoxicol. News 1 : 15-22.

Dahl B. 1996. - On the ecotoxicology of antifouling agents, the use of marine microalgal communities in predictive and restrospective assessments. Thesis, Univ. of Göteborg : 45 p. +5 papers.

Dahl B. \& Blanck H. 1996. - Toxic effects of the antifouling agent 1051 on periphyton commuities in coastal water microcosms. Mar. Poll. Bull., 32 : 342-350.

DeNoyelles F.-Jr., Kettle W.D. \& Sinn D.E. 1982. — The responses of plankton communities in experimentals ponds to atrazine, the most heavily used pesticide in the United States. Ecology, 63 : 1285-1293.

Eulin A. 1997. - Les communautés de Diatomées épilithiques de la garonne. Répartition naturelle et étude expérimentale de la dynamique de colonisation sur substrat artificiel. Thèse $3^{\text {ème }}$ cycle, Univ. Toulouse III, France : 248 p.

Giovanni R. \& Haury J. 1995. - Pesticides et milieu aquatique, in Actes du colloque CORPEP/Bretagne Eau Pure "Qualité des eaux et produits phytosanitaires : du diagnostic à l'action", Rennes, 27 Novembre 1995 : 57-70.

Guasch H. \& Sabater S. 1998. - Light history influences the sensitivity to atrazine in periphytic algae. J. Phycol., $34: 233-241$.

Gurney S.E. \& Robinson G.G.C. 1989. - The influence of two triazine herbicides on the productivity, biomasse and community composition of freshwater marsh periphyton. Aquat. Bot., 36 : $1-22$.

Hamala J.A. \& Kollig H.P. 1985. - The effects of atrazine on periphyton communities in controlled laboratory ecosystems. Chemosphere, 14 (9) : 1391-1408.

Herman D., Kaushik N.R. \& Solomon K.R. 1986. - Impact of atrazine on periphyton in freshwater enclosures and some eological consequences. Can. J. Fish. Aquat. Sci., 43 : 1917-1925.

Jeffrey S.W. \& Humphrey G.F. 1975. - New spectrophotometric equations for determining chlorophylls $a, b, c_{1}$ and $c_{2}$ in higher plants, algae and natural plankton. Biochem. Physio. Pflanz., $167: 191-194$.

Jurgensen T.A. \& Hoagland K.D. 1990. - Effects of short-term pulses of atrazine on attached algal communities in a small stream. Arch. Environ. Contam. Toxicol., $19: 617-623$.

Källsqvist T. \& Romstad R. 1994. - Effects of agricultural pesticides on planktonic algae and cyanobacteria. Examples of inter- species sensitivity variations. Norv. J. Agricul. Sci., 13 : 133-152.

Kasai F. 1999. - Shifts in herbicide tolerance in paddy field periphyton following herbicide application. Chemosphere, 38 (4) : 919-931.

Kosinski R.J. 1984. - The effect of terrestrial herbicides on the community structure of stream periphyton. Environ. Pollut., 76 : 201-210.

Kraufvelin P. 1998. - Model ecosystem replicability challenged by the "soft" reality of a hard bottom mesocosm. J. Exp. Mar. Biol. Ecol., 222 : 247-267.

Krieger K.A., Baker D.B. \& Kramer J.W. 1988. - Effects of herbicides on stream Aufwuchs productivity and nutrient uptake. Arch. Environ. Contam. Toxicol., 17 : 299-306.

Lecointe C., Coste M. \& Prygiel J. 1993. - "Omnidia" : software for taxonomy, calculation of diatom indices and inventories management. Hydrobiologia, 269/270 : 509-513.

Lowe R., Guckert J.B., Belanger S.E., Davidson D.H. \& Johnson, D.W. 1996. - An evaluation of periphyton community structure and function on tile and cobble substrata in experimental stream mesocosms. Hydrobiologia, 328 : 135-146.

Millerioux G. 1975. - Comparaison des méthodes spectrophotométriques pour le calcul des pigments phytoplanctoniques. Ann. Stat. Biol. Besse-en-Chandesse, 9: 7-59.

Müller U. 1995. - Vertical zonation and production rates of epiphytic algae on Phragmites australis. Freshwat Biol., $34: 69-80$.

Nyström B.A. 1997. - Metabolic indicators of ecotoxicological effects in freshwater periphyton communities. Thesis Univ. Göteborg : 26 p. +5 papers.

Odum Z.P. 1984. - The mesocosm. Bioscience, $34: 558-562$.

Pérès F., Coste M., Ribeyre F., Ricard M. \& Boudou A. 1997. - Effects of methylmercury and inorganic mercury on periphytic diatom communities in freshwater indoor microcosms. J. Appl. Phycol., $9: 215-227$.

Pratt R.R., Bowers N.L., Niederlehner B.R. \& Cairns J. 1988. - Effects of atrazine on freshwater microbial communities. Arch. Environ. Contam. Toxicol., $17: 449-457$.

Prygiel J., Lévêque L. \& Iserentant R. 1996. — Un nouvel indice diatomique pratique pour l'évaluation de la qualité des eaux en réseau de surveillance. Rev. Sci. Eau., 1 : 97-113.

Schagerl M. \& Donabaum K. 1998. - Epilithic algal communities on natural and artificial substrata in the River Danube near Vienna (Austria). Large Rivers Vol. 11, No. 2. Arch. Hydrobiol., $115 / 2: 153-165$.

Seguin F., Leboulanger C., Rimet F., Druart J.-C. \& Berard A. 2001. - Effects of atrazine and nicosulfuron on phytoplankton in systems of increasing complexity. Arch. Environ. Contam. Toxicol., : 40 (2) : 198-208.

Simpson D.M., Stoller E.W. \& Wax L.M. 1995. - An in vivo acetolactate assay. Weed Techno., $9: 17-22$

Touart L.W. 1994. - Regulatory endpoints and the experimental design of aquatic mesocosms tests, In Aquatic mesocosms studies in ecological risk assessment. Graney, R.L., Kennedy J.H. \& Rodgers, J.H., Jr. (eds.). Lewis, Boca Raton, chap. 4 : 25-33.

Utermöhl H. 1958. - Zur Vervollkommnung der.quantitativen Phytoplanktonmethodik. Mittlg. Internat. Verein. Limnol., 9 : 1-38.

Van Den Brinck P.J., Hartgers E.M., Fettweis U., Crum S.J.H., Van Donk E. \& Brock T.C. M. 1997. - Sensitivity of macrophyte-dominated freshwater microcosms to chronic levels of the herbicide linuron. Ecotox. Environ. Saf., 7 : 925-929.

Vinebrooke D. \& Graham, M.D. 1997. - Periphyton assemblages as indicators of recovery in acidified Canadian Shield lakes. Can. J. Fish Aquat. Sci., 54 : 1557-1568.

Whitton B.A. \& Rott E. 1996. - Use of Algae for monitoring rivers II. In Proceedings of an International Symposium II. Whitton B.A. \& Rott E. (eds), Innsbruck, Austria, 17-19 Sept. 95 : 196 p. 